\title{
UTILIZATION OF WASTEWATER FOR CORROSION PREVENTION OF CARBON STEEL PIPE USING SINGLE CHAMBER MICROBIAL FUEL CELLS
}

\author{
M.Z. Suhaili, M.D.M. Samsudin
}

\author{
Department of Energy Engineering, Faculty of Chemical and Energy Engineering, Universiti Teknologi Malaysia, 81310 UTM Johor Bahru, Johor, \\ Malaysia.
}

*Corresponding Author Email: dinie@utm.my

This is an open access article distributed under the Creative Commons Attribution License, which permits unrestricted use, distribution, and reproduction in any medium, provided the original work is properly cited

\section{ARTICLE DETAILS}

\section{Article History:}

Received 10 May 2018 Accepted 6 Jun 2018 Available online 10 July 2018

\section{ABSTRACT}

This study applies a concept Microbial Fuel Cells (MFCs) in a biological cathodic protection (CP) system. The biological CP uses the microbial properties of living microorganisms which are able to produce electrons and suffice the requirement for $\mathrm{CP}$ in corrosion prevention system. The electrons produce by the bacteria will be diffuse and transfer to the surface area of graphite which is use as anode. The objective of MFCs for CP is to achieve an optimum value of electro potential produce by bacteria inoculated in MFCs system as preventive measures against corrosion occurred in commonly used carbon steel pipeline. The purpose of the study is to identify the wastewater derived from industry, estuary and dairy farm animal that can give the nearest optimum value of $-850 \mathrm{mV}$ for CP. Prior to the objective, three different types of waste is choose as samples in this study which are palm oil mill effluent (POME), estuary water and goat's feces. Wastewater such as POME and estuary water is stored in a freezer at the temperature below 4oC. Meanwhile goat's feces is soak in distill water for 24 hours before it is place in a freezer. After the collection of wastewater, a proximity analysis such as $\mathrm{pH}$, conductivity, salinity, COD and TSS is conducted to determine the quality of the wastewater. The 4 liter of wastewater is place in a rig and $40 \mathrm{~g}$ of sodium acetate as substrate is mix so that it will act as medium for bacteria growth in a single chamber MFCs. The backfilling for the experiment is sand with sand to wastewater is $2 \mathrm{~L}$ and $4 \mathrm{~L}$ respectively. The anode (graphite) will undergoes treatment to remove contamination by soaking it in a $100 \%$ ethanol for 30 minutes and then soak in $1.0 \mathrm{M} \mathrm{HCl}$ for one hour. The electro potential reading is record periodically in hourly basis using electrical multi meter for each source of wastewater and correspondent current density and power density will be determined. In the experiment, three samples is used to represents the population of each type of wastewater in order to have accurate reading and more reliable results during analysis. A statistical analysis is use for the purpose of fulfilling the objective of the study. The result of study shows that wastewater from goat's feces gives the lowest rate of corrosion which is 1.18 x 10-6 kg/h and followed by estuary water and palm oil mill effluent of 4 x 10-6 kg/h and 7.18 x 10-6 kg/h respectively. It is also found that the wastewater from goat's feces achieved the highest mean negative potential of $578.07 \mathrm{mV}$ while standard cathodic protection is $-850 \mathrm{mV}$.

\section{KEYWORDS}

Industrial wastewater, Estuary wastewater, Dairy farm animal wastewater, Biological cathodic protection, living microorganisms to produce electrons

\section{INTRODUCTION}

Corrosion is a result of electrochemical reaction that occurs within the pipelines. To control the corrosion a Cathodic Protection (CP) approach is the best method available. CP is a technical application aim to reduce corrosion rate of a metal surface by reversing the metal character which is anodic in nature into a cathodic properties in anticipation to significantly decrease its natural character as an electron donor. Previously there are two methods for $\mathrm{CP}$ which are sacrificial anode and Impressed Current Cathodic Protection (ICCP). The sacrificial anode has poor performance when use in high resistivity of soil area and consequence in very low current output that fails to maintain a largescale pipeline structure unless the large number of anode is installed to satisfy the conditions, but it practically raise the cost.

The ICCP that is powered by AC became an issue when used in a remote area in which the AC gridline is not available and other expensive alternatives must be adopted. Therefore, other alternative method should make way for similar objectives and in this case the practical approach of corrosion prevention is Cathodic Protection (CP) through bacteria producing electron which inoculated in a Microbial Fuel Cells (MFCs). The CP technique of MFCs uses the advantage of the microbial properties of a living microorganisms in which it is potentially able to produce electrons and therefore fulfill the requirement for $\mathrm{CP}$ in corrosion prevention system. The system uses the benefit of bacteria or microorganism presents in the wastewater that are able to generate electrons [1].

Thus, the investigation of wastewater containing electron is intending to look for the wastewater suffice for $\mathrm{CP}$ and to lessen the corrosion rate in pipeline. The quest for such microorganisms is attempted through different types of wastewater that has a potential to contain electron producing bacteria [2]. Such ability will increase the number of electron transfer into anode by the bacteria and finally assist to raise the negative potential of an anode and hence protecting the cathode from corrosion. However, the ability to protect cathode from corrosion requires certain optimum electrical potential (voltage) values as proxy to the number of electrons generated. For a metal such as steel the required optimum voltage is $-850 \mathrm{mV}$ [3].

Therefore, the potential wastewater must be carefully selected in order to satisfy the required optimum potential before experiment can be perform. The wastewater selects come from three different types namely originate from river, animal farm and palm oil effluent. The selection is 
due to the high current density and power density it can produce. The voltage produces by river, animal waste and palm oil effluent is $0.6-0.9 \mathrm{~V}$, 0.6-0.8 $\mathrm{V}$ and 0.75-0.80 V respectively [4-6].

\section{EXPERIMENTAL}

The experiment is designated for a single chamber MFCs that comprise of the anode (graphite), cathode (carbon steel) and electrolyte.

\subsection{Sample Preparation}

The wastewater is obtained from three different sites that come from river, animal waste farm and oil palm mill effluent. The wastewater from river is collect at Sg. Pontian Besar, Pontain Johor, animal waste (goat's feces) from poultry farm at Masai, and oil palm effluent is at Bell Palm Industries Sdn Bhd located at Johor Bahru. The goat's feces firstly exposed to open air for 24 hours and soaks in distilled water for one night before it is subdued to study. All the wastewater will immediately preserve in a temperature below $4^{\circ} \mathrm{C}$ in order to retain the bacterial activities and to prolong their life cycles.

\subsection{Material Selection}

\subsubsection{Anode}

Graphite rod is use as anode in this experiment due to chemically stable character and most versatile and high mechanical strength [4]. The dimension of the graphite rod is $12 \mathrm{~cm}$ height $\mathrm{x} 2 \mathrm{~cm}$ diameter. The new graphite rod should undergo treatment before it can be utilizing. The purpose treatment is to remove possible metal and inorganic contamination [4]. Graphite rod is soaked in $100 \%$ ethanol for 30 minutes and $1.0 \mathrm{M} \mathrm{HCl}$ for 1 hour. After each use, the graphite is soak in $1.0 \mathrm{M} \mathrm{HCl}$ for 1 hour followed by $1.0 \mathrm{M} \mathrm{NaOH}$ for another 1 hour and stored in distilled water until the next usage.

\subsubsection{Cathode}

Cathode material is carbon steel pipe. Carbon steel pipe which is choose according to Schedule 40 Pipe Dimension due to its common usage as gas pipeline material used in Malaysia [7]. A standard dimension size of $3 / 4$ inch, $26.67 \mathrm{~mm}$ outer diameter, $20.93 \mathrm{~mm}$ internal diameter and $2.87 \mathrm{~mm}$ nominal thickness is used.

\subsubsection{Sand}

Sand is used as backfilling in the single chamber compartment. Two liters of sand with size between $0.105 \mathrm{~mm}-0.250 \mathrm{~mm}$ is used. The experiment is carried out with the ratio of backfilling to the wastewater of $2 \mathrm{~L}: 4 \mathrm{~L}$ respectively [8]. Sand is selected as backfilling because spaces between sand particles are able to trap oxygen and hence provides it to form water when combined with protons [8].

\subsubsection{Reference electrode}

Saturated $\mathrm{Cu} / \mathrm{CuSO} 4$ is used as reference electrode to measure the potential difference between anode and cathode.

\subsection{Substrate Selection}

\subsubsection{Type of substrate}

The substrate used is sodium acetate of volume $40 \mathrm{~g}$ per rig were fed into single chamber compartment (rig). The used of sodium acetate is to provide food source for the bacteria and hence promotes its ability to energize and activate the electro active bacteria. Acetate is used also for a reason that it has inert properties against microbial conversion at room temperature and therefore extensively being used as standardization of MFC [9].

\subsection{Experimental \& Procedure}

\subsubsection{Proximity Test}

A proximity test will be conducted for each sample after it is collected in order to determine the quality of the wastewater. The proximity analysis is focused on their pH, conductivity, salinity, Total Suspended Solid (TSS), Chemical Oxygen Demand (COD) and conductivity. The volume collected for each wastewater samples are five liters.

\subsubsection{Single Chamber MFCs}

A single chamber MFCs or rig is set up using a dark plastic container. The experiment is conducted in a batch fed mode at a room temperature. Four liters of wastewater and two liters of sand as backfilling were used. The graphite anode is immersed in wastewater while carbon steel pipe is dip fully into the sand. Copper wire is use to connect both anode and cathode to a multi meter [10]. A $40 \mathrm{~g}$ per rig of sodium acetate were fed into the chamber to increase the microbial growth rate of the wastewater. Voltage and current is taken regularly for every 2 hours until the value is decreasing indicating the bacteria has reached their death phase. This experiment uses 3 types of wastewater and each type will have 3 samples being study at simultaneous time and it will be repeated with other wastewater sequentially [11]. The data obtained will be analyzed statistically in search for reliable data and to test the confidence level of the data. The physical quantities such as electrical potential, current density and power density are calculated for each run and presented in Table 1.

Table 1: Mean Current \& Voltage for Three Different Types of Wastewater

\begin{tabular}{|c|c|c|c|c|c|c|}
\hline \multirow[t]{3}{*}{ Type of Wastewater } & \multicolumn{6}{|c|}{ Reading } \\
\hline & \multicolumn{3}{|c|}{ Mean Current (mA) } & \multicolumn{3}{|c|}{ Mean Voltage $(\mathrm{mV})$} \\
\hline & S1 & S2 & S3 & S1 & S2 & S3 \\
\hline Estuary & 2.308 & 0.243 & 1.792 & 604.800 & 414.550 & 552.300 \\
\hline Goat's feces & 1.315 & 0.823 & 0.997 & 684.458 & 505.417 & 627.458 \\
\hline Palm oil mill effluent & 0.154 & 0.191 & 0.704 & 637.214 & 552.857 & 518.393 \\
\hline
\end{tabular}

\subsubsection{Study of electrode potential \& current}

The value of electrode potential is measured against the reference electrode periodically (hourly basis) that lasted for 6 days and repeated three times ( 3 runs). The experiment is carried out with the ratio of backfilling to the wastewater of $2 \mathrm{~L}: 4 \mathrm{~L}$. The performance of wastewater is observed based on the achievement of $-850 \mathrm{mV}$ which is the optimum value of $\mathrm{CP}$.

\subsection{Calculation}

\subsection{1 $p H$}

The term $\mathrm{pH}$ refers to the measurement of hydrogen ion in the solution. The $\mathrm{pH}$ of electrolyte is measure using a pH meter (PHS-3D).

\subsubsection{Conductivity}

Conductivity is a measure of water's capability to pass electrical flow and it is directly related to the concentration of ions in water. The value of conductivity is measure using 'Abron TDS meter'. 


\subsubsection{Salinity}

Salinity is the concentration of all dissolved salts in water. The salinity is measure using 'Abron TDS Meter'.

\subsubsection{Total suspended solid, TSS}

Apparatus: Glass fiber filters, oven, analytical weight, pump Material: $\quad$ Water sample, distilled water

The glass fiber filter is prepared by soaking in distilled water and dried at $103^{\circ} \mathrm{C}$. The prepared filter is weighed and recorded. The prepared filter is placed in filtering flask with wrinkled side up. The sample bottle is shaking and poured in the water and the pump in turned on. The volume of water filtered is recorded. The filter is dried at $103^{\circ} \mathrm{C}$ and $105^{\circ} \mathrm{C}$ and cooled at room temperature and is weighed again until the fiber reached a constant weight. The end weight is recorded. The increase in weight (the difference) represents TSS and can be calculated by using equation (1) below.

$$
\text { TSS }(\mathrm{mg} / \mathrm{L})=\left[(\mathrm{A}-\mathrm{B})^{*} 1000\right] / \mathrm{C}
$$

Where,

$$
\begin{aligned}
& A=\text { End weight of the filter } \\
& B=\text { Initial weight of the filter } \\
& C=\text { Volume of water filter }
\end{aligned}
$$

\subsubsection{Chemical oxygen demand, COD}

Chemical oxygen demand is a test that measures the number of organic compounds in water and represents a measure of oxygen required to oxidize all compounds both organic and inorganic in water. The calculation for COD is given in the equation (2),
COD $=(a-b) \times c \times \frac{8000}{\text { volume }}$ of sample in $m L$

Let 'a' represent the titrant used for sample $(\mathrm{mL})$

Let ' $b$ ' represent the titrant used for blank sample (mL)

Let 'c' represent normality of wastewater

Table 2 below shows the result of COD for three different types of wastewater recorded.

Table 2: COD of Three Different Types of Wastewater

\begin{tabular}{|l|c|}
\hline \multicolumn{1}{|c|}{ Types of Wastewater } & COD (mg/L) \\
\hline Palm Oil Mill Effluent & 1028 \\
\hline Estuary Water & 4415 \\
\hline Goat's Feces & 3618 \\
\hline
\end{tabular}

\subsubsection{Current density \\ 2.5.7}

Current density can be calculated using equation (3),

Current density $=\frac{I}{A}$

Where,

$$
\begin{aligned}
& \mathrm{I}=\text { Current in the circuit }(\mathrm{mA}) \\
& \mathrm{A}=\text { Surface area of the cathode }\left(\mathrm{m}^{2}\right)
\end{aligned}
$$

Table 3 represents calculated mean current density of three types of wastewater. Estuary water shows the highest mean current density that influx upon the electrode followed by goat's feces, meanwhile palm oil mill effluent scores about $24 \%$ lower as compared to the highest value.

Table 3: Mean Current Density for Three Different Types of Wastewater

\begin{tabular}{|l|c|}
\hline \multicolumn{1}{|c|}{ Types of Wastewater } & Mean Current Density (mA/m $\left.\mathbf{m}^{2}\right)$ \\
\hline Palm Oil Mill Effluent & 13.90 \\
\hline Estuary Water & 58.16 \\
\hline Goat's Feces & 42.48 \\
\hline
\end{tabular}

\subsubsection{Power density}

Power density can be calculated by using equation (4),

Power density $=$ Mean Voltage $x$ Current Density

Table 4: Mean Power Density for Three Different Types of Wastewater

\begin{tabular}{|l|c|}
\hline \multicolumn{1}{|c|}{ Types of Wastewater } & $\begin{array}{c}\text { Mean Power Density } \\
\left(\mathbf{m W} / \mathbf{m}^{2} \text { ) }\right.\end{array}$ \\
\hline Palm Oil Mill Effluent & 8159.03 \\
\hline Estuary Water & 26369.47 \\
\hline Goat's Feces & 22457.20 \\
\hline
\end{tabular}

Table 4 shows the mean power density acquire by both estuary water and goat's feces are the highest value while palm oil mill effluent scores about $31 \%$ lower compared to the highest value.

\subsection{Data Analysis}

Comparing the data sets from three different types of wastewater and to determine which data set will satisfy or nearly reach the optimization value of cathodic protection. The ANOVA (analysis of variance) can be used for the purpose of evaluating differences between the data sets.

\section{RESULT}

\subsection{Proximity Analysis of Wastewater}

The purpose of analysis is to know the characteristics of wastewater collected from various sources. The proximity analysis is focused on the pH (PHS-3D), salinity (Abron TDS meter), Total Suspended Solid (TSS), Chemical Oxygen Demand (COD) and conductivity (Abron TDS meter). Table 6 shows the result of proximity test in one of wastewater sample.
Table 6: Wastewater Proximity Analysis

\begin{tabular}{|l|c|c|c|}
\hline \multirow{2}{*}{ Parameter } & \multicolumn{3}{|c|}{ Reading } \\
\cline { 2 - 4 } & $\begin{array}{c}\text { Palm Oil } \\
\text { Effluent }\end{array}$ & $\begin{array}{c}\text { Estuary } \\
\text { Water }\end{array}$ & $\begin{array}{c}\text { Goat's } \\
\text { feces }\end{array}$ \\
\hline $\mathrm{pH}$ & 9.60 & 6.79 & 8.23 \\
\hline Conductivity, $\mu$ MHOS & 1890 & 5000 & 230 \\
\hline Salinity, S\% & 2.30 & 3.00 & 0.50 \\
\hline $\begin{array}{l}\text { Total Suspended Solid, TSS } \\
\text { (mg/L) }\end{array}$ & 192.00 & 273.00 & 161.00 \\
\hline $\begin{array}{l}\text { Chemical Oxygen Demand, } \\
\text { COD (mg/L) }\end{array}$ & 1028.00 & 4415.00 & 3618.00 \\
\hline
\end{tabular}

Based on Table 6, the initial condition of wastewater was in base condition for palm oil mill effluent and goat's feces but slightly acidic for estuary water. The conductivity is a measure of the ability of water to pass an electrical current and estuary water has the highest measure of conductivity. The TSS shows that estuary water has highest turbidity and suggests that bacteria, germs and other chemical constituent precipitates were dissolved in the wastewater. The COD reading that shows the amount of oxygen required for oxidation reaction of the microorganisms is also highest for estuary water and goat's feces as compared to palm oil mill effluent.

\subsection{Electrode Potential and Current}

In the experiment, each type of wastewater had a number of three samples examine simultaneously. Table 7 shows the results of potential and current obtained from three different types of wastewater which run in a particular period of time in hourly basis. All types of wastewater have been subjected to the period of 120 hours of data collection. 
Table 7: Current and Voltage of Three Different Types of Wastewater

\begin{tabular}{|c|c|c|c|c|c|c|}
\hline \multirow[t]{2}{*}{ Type of Wastewater } & \multicolumn{3}{|c|}{$\begin{array}{c}\text { Current } \\
\text { mA }\end{array}$} & \multicolumn{3}{|c|}{$\begin{array}{c}\text { Voltage } \\
\text { mV }\end{array}$} \\
\hline & R1 & R2 & R3 & R1 & R2 & R3 \\
\hline \multirow[t]{12}{*}{$\begin{array}{l}\text { Wastewater from } \\
\text { river }\end{array}$} & 5.95 & 0.48 & 5.46 & 600 & 300 & 581 \\
\hline & 5.31 & 0.47 & 4.48 & 620 & 257 & 590 \\
\hline & 3.24 & 0.59 & 4.32 & 693 & 310 & 559 \\
\hline & 3.34 & 0.43 & 4.21 & 691 & 292 & 602 \\
\hline & 2.56 & 0.32 & 2.98 & 693 & 293 & 572 \\
\hline & 2.84 & 0.38 & 2.48 & 690 & 297 & 610 \\
\hline & 2.49 & 0.35 & 2.24 & 702 & 306 & 615 \\
\hline & 2.83 & 0.15 & 2.77 & 703 & 300 & 612 \\
\hline & 1.50 & 0.06 & 1.07 & 701 & 327 & 624 \\
\hline & 2.03 & 0.25 & 1.98 & 545 & 318 & 596 \\
\hline & 2.06 & 0.21 & 0.54 & 589 & 291 & 687 \\
\hline & 1.66 & 0.18 & 0.94 & 585 & 301 & 558 \\
\hline \multirow[t]{12}{*}{$\begin{array}{l}\text { Wastewater from } \\
\text { animal farm }\end{array}$} & 5.69 & 1.51 & 7.55 & 570 & 531 & 620 \\
\hline & 2.60 & 4.20 & 0.17 & 727 & 406 & 622 \\
\hline & 2.32 & 3.40 & 1.21 & 744 & 405 & 645 \\
\hline & 2.63 & 3.02 & 0.57 & 755 & 684 & 630 \\
\hline & 2.36 & 2.65 & 4.46 & 760 & 435 & 625 \\
\hline & 0.12 & 0.10 & 0.22 & 772 & 467 & 751 \\
\hline & 1.90 & 0.90 & 0.50 & 770 & 404 & 743 \\
\hline & 0.14 & 0.84 & 0.65 & 763 & 369 & 635 \\
\hline & 1.94 & 0.80 & 0.70 & 798 & 410 & 625 \\
\hline & 0.18 & 1.60 & 0.90 & 755 & 428 & 696 \\
\hline & 0.09 & 0.15 & 0.24 & 615 & 418 & 766 \\
\hline & 0.07 & 0.03 & 0.20 & 757 & 429 & 772 \\
\hline \multirow[t]{12}{*}{ Palm oil mill effluent } & 0.38 & 0.58 & 1.16 & 689 & 670 & 473 \\
\hline & 0.44 & 0.67 & 1.41 & 710 & 629 & 503 \\
\hline & 0.29 & 0.31 & 1.55 & 753 & 639 & 469 \\
\hline & 0.18 & 0.31 & 1.13 & 748 & 654 & 477 \\
\hline & 0.24 & 0.34 & 0.72 & 753 & 668 & 489 \\
\hline & 0.01 & 0.01 & 0.58 & 760 & 678 & 498 \\
\hline & 0.12 & 0.22 & 1.30 & 773 & 720 & 487 \\
\hline & 0.11 & 0.20 & 1.62 & 772 & 715 & 526 \\
\hline & 0.04 & 0.18 & 1.70 & 771 & 704 & 530 \\
\hline & 0.03 & 0.16 & 0.68 & 700 & 696 & 489 \\
\hline & 0.03 & 0.13 & 0.58 & 689 & 610 & 460 \\
\hline & 0.05 & 0.16 & 0.40 & 601 & 629 & 462 \\
\hline
\end{tabular}




\section{Mean Voltage (mV)}

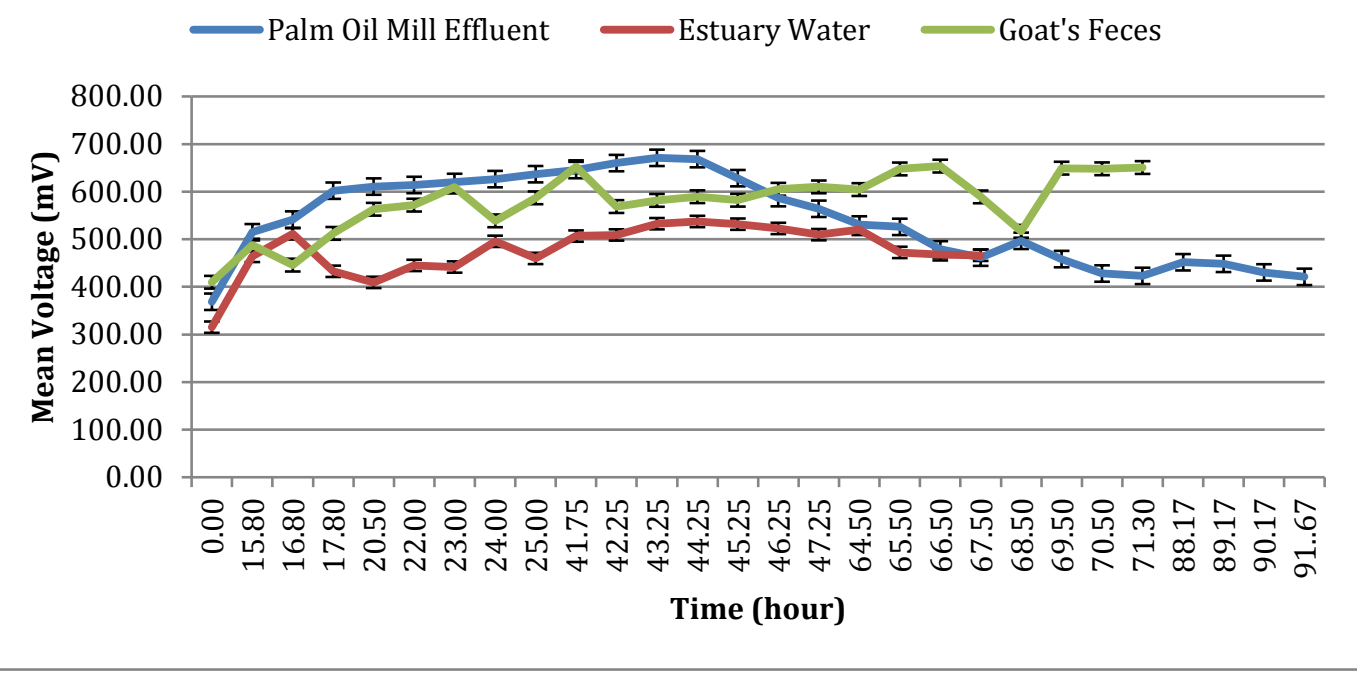

Figure 1: Graph of mean voltage $(\mathrm{mV})$ over period of time for Three Different Types of Wastewater

Based on the data obtained from the three samples, the mean average value of each samples were calculated and the graph of voltage $(\mathrm{mV})$ against period of time in hour is plotted. Graph 1 shows the trend line for estuary water, palm oil effluent and goat's feces wastewater. Overall, the profile of voltage for three different types of wastewater had undergoes four phases which are the lag phase, exponential phase, stationary phase and death phase.

The lag phase is the phase where bacteria adapting themselves to the growth condition. The exponential phase is when the bacteria experience rapid growth and reproduction and thus it became a large number of populations. The exponential phase occurs at different period of each wastewater. For POME, estuary water and goat's feces, the exponential phase occur at 0 to 40 hours, 0 to 45 hours and 0 to 70 hours respectively. The highest voltage profile of wastewater indicates the electrons occurrence is in abundance in the particular wastewater. The stationary phase however is due to the limiting factor such as depletion in nutrients and the reproduction and death of bacteria are in equilibrium.

\subsection{Statistical Analysis}

The statistical analysis of ANOVA is applied to determine the optimum value of electric potential. The analysis includes standard deviation, standard error and confidence level at $95 \%$ by using equation (5), (6) and (7) respectively. Table 8 shows the sample of expected results for the three experimental data and the value of the analysis which consist value of standard deviation, standard error and the confidence level of the data.

$$
S=\sqrt{\frac{1}{N-1} \sum_{i=1}^{N}\left(x_{i}-\bar{x}\right)^{2}}
$$

Where,

S: standard deviation

$\mathrm{N}$ : number of run

$\mathrm{x}_{\mathrm{i}}$ : individual values of $\mathrm{x}$

$\mathrm{x}$ : mean

$S_{M}=\frac{S}{\sqrt{N}}$

$C L(\mu)=\bar{x} \pm \frac{t s}{\sqrt{N}}$

Where,

$\mathrm{t}$ : depend on degree of freedom, $\mathrm{v}(\mathrm{N}-1)$ and confidence level of $95 \%$.

Table 8: Summary of Standard Deviation, Standard Error and Confidence Interval for Three Different Types of Wastewater

\begin{tabular}{|c|c|c|c|c|}
\hline Run & Mean & $\begin{array}{c}\text { Standard } \\
\text { Deviation }\end{array}$ & $\begin{array}{c}\text { Standard } \\
\text { Error }\end{array}$ & $\begin{array}{c}\text { Confidence } \\
\text { Level }\end{array}$ \\
\hline POME* & 539.73 & 300 & 75.51 & 85.69 \\
\hline $\begin{array}{c}\text { Estuary } \\
\text { Water }\end{array}$ & 477.55 & 332 & 71.83 & 87.45 \\
\hline Goat's Feces & 578.07 & 438 & 84.17 & 94.95 \\
\hline
\end{tabular}

*POME (Palm Oil Mill Effluent)

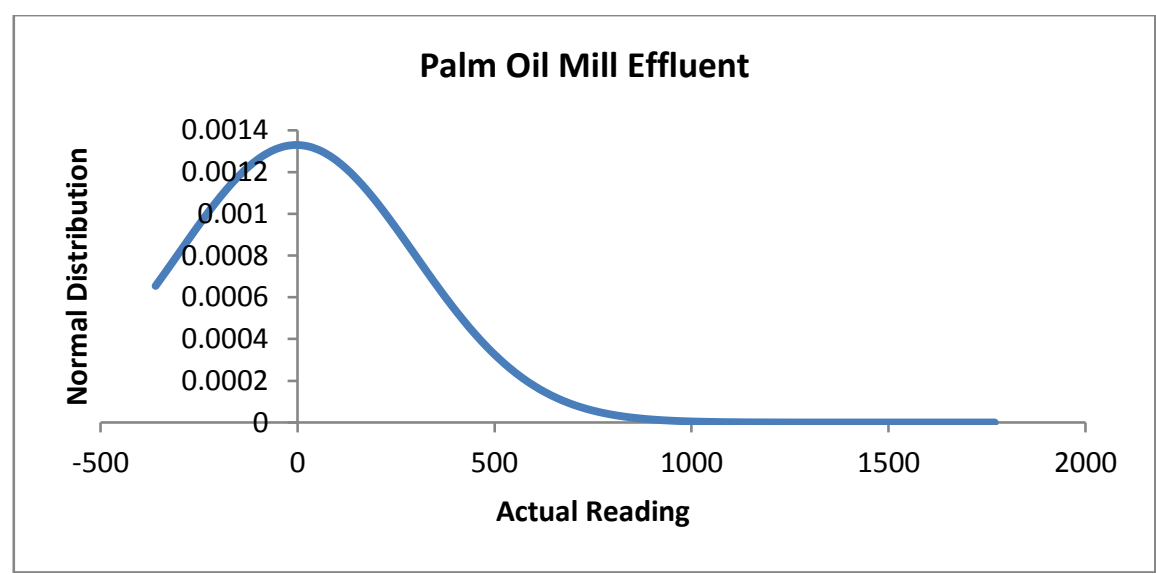

Figure 2: Normal Distribution Curve Graph of Palm Oil Mill 


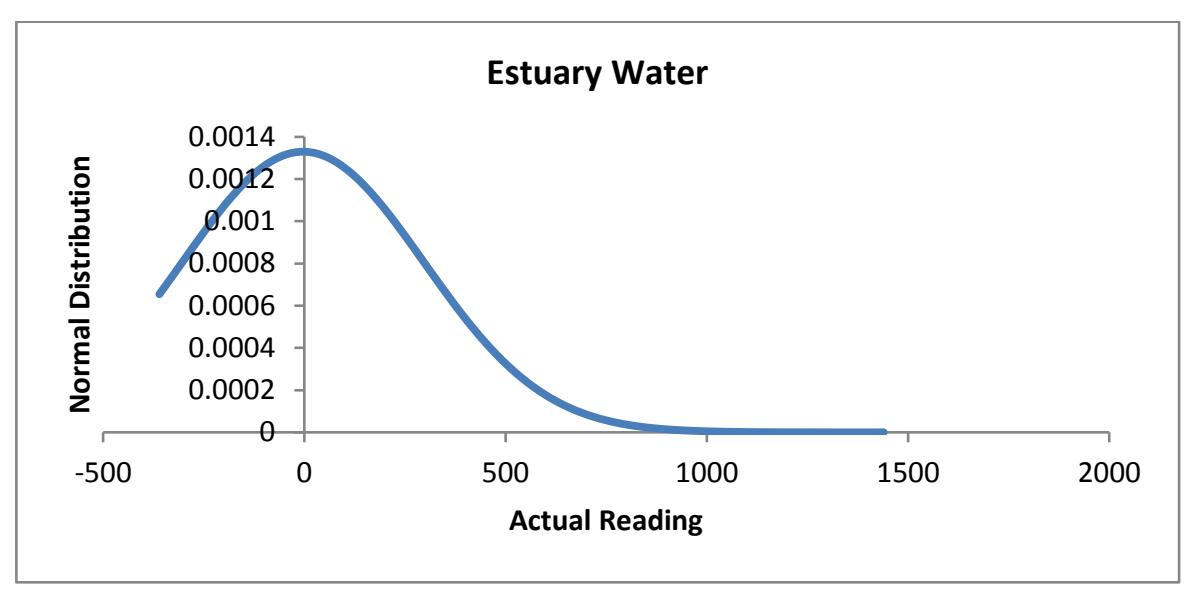

Figure 3: Normal Distribution Curve Graph of Estuary Water

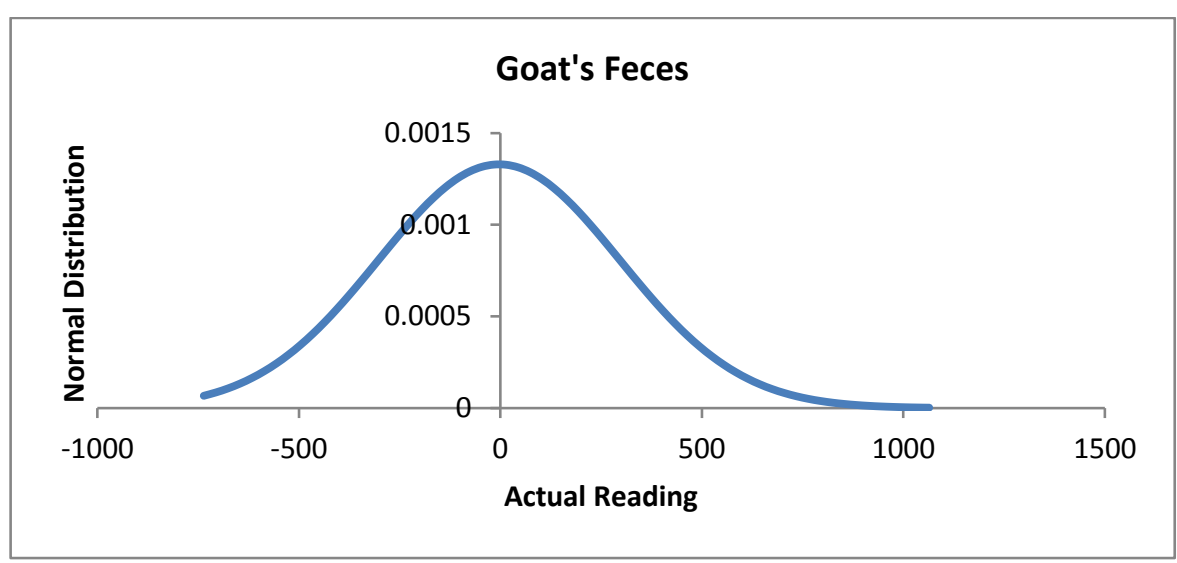

Figure 4: Normal Distribution Curve Graph of Goat's Feces

According to the data obtain in Table 8, the normal distribution graph is attempt to be drawn, and all wastewater samples shows the normal distributed curve as shown in Figure 2, 3 and 4. Among the wastewater, goat's feces have the highest confidence level of $94.95 \%$ compared to the other even though POME and estuary possess a quite high confidence level. This indicates that goat's feces wastewater had a reliable data and scores the highest value of mean voltage followed by POME and estuary water.

\section{CONCLUSION}

This study is to investigate the selected wastewater that will give the lowest corrosion rate in order to reduce corrosion in carbon steel pipe and to determine the wastewater that has the nearest value to the standard cathodic protection of $-850 \mathrm{mV}$. It is found that among the examine wastewater, goat's feces have performed the lowest rate of corrosion of $1.18 \times 10^{-6} \mathrm{~kg} / \mathrm{h}$ as compared to the other two followed by estuary water and palm oil mill effluent. It is also found that the wastewater from goat's feces achieved the highest mean negative potential of $-578.07 \mathrm{mV}$ while standard cathodic protection is $-850 \mathrm{mV}$. Nevertheless, estuary wastewater had shown more reliable data due the higher confidence level and data which is more normally distributes compared to another wastewater. Therefore, none of the wastewater used had achieved the standard cathodic protection value, and hence this study can give space to other investigation on how to improve the performance of these potential wastewaters in order to increase its potential value.

\section{REFERENCES}

[1] Heidrich, E.S., Curtis, T.P., Woodcock, S., Dolfing, J. 2016. Quantification of Effective Exoelectrogens by Most Probable Number, 218, 27

[2] Velasquez Orta, S.B., Head, I.M., Curtis, T.P., Scott, K. 2011. Factors Affecting Current Production in Microbial Fuel Cells Using Different
Industrial Wastewaters, 102, 5105-5112.

[3] Masli, A.B. 2011. Interaction between Cathodic Protection and Microbially Influenced Corrosion. PhD. Univeristy of Manchester.

[4] Prabu, M., Durgadevi, M., Tamilvendan, M., Kalaichelvan, P.T., Kaviyarasan, V. 2012. Electricity Production from Waste Water Using Microbial Fuel Cell, 1, 19-25.

[5] Oladejo, D., Shoewu, O.O., Yussouff, A.A., Rapheal, H. 2015. Evaluation of Electricity Generation from Animal Based Wastes In A Microbial Fuel Cell, 4,85.

[6] Jong, B.C., Liew, P.W.Y., Juri, M.L., Kirn, B.H., Mohd Dzomir, A.Z., Leo, K.W., Awang, M.R. 2011. Performance and Microbial Diversity of Palm Oil Mill Effluent Microbial Fuel Cell. 53, 660-667.

[7] SIRIM. 2016. Installation of fuel gas piping systems and appliances Code of practice (Second Revision).

[8] Kim, B.H., Chang, I.S., Gadd, G.M. 2007. Challenges in Microbial Fuel Cell Development and Operation, 76, 485-494.

[9] Deepak, Pant. 2009. A review of the substrates used in microbial fuel cells (MFCs) for sustainable energy production, 101, 15331543.

[10] Wang, Z., Wu, Z. 2013. Power Production from Different Types of Sewage Sludge Using Microbial Fuel Cells: A Comparative Study with Energetic and Microbiological Perspectives. 235, 280-288.

[11] Khan, M.D., Abdulateif, H., Ismail, I.M.I.S., Khan, M.Z. 2015. Bioelectricity Generation and Bioremediation of an Azo-Dye in a Microbial Fuel Cell Coupled Activated Sludge Process, 10, 1-18. 